\title{
ODTWORZENIE PRZEBIEGU LINII OKOPÓW Z II WOJNY ŚWIATOWEJ (OKH Stellung b1) W PAŚMIE JALOWIECKIM I GRUPIE MĘDRALOWEJ NA PODSTAWIE NUMERYCZNEGO MODELU TERENU Z DANYCH LiDAR I BADAŃ TERENOWYCH
}

\begin{abstract}
Zarys treści: Artykuł prezentuje możliwość wykorzystania modeli terenu pochodzących z danych LiDAR do odtworzenia elementów historycznych fortyfikacji polowych. Podczas badań odtworzono przebieg linii okopów pochodzących z II wojny światowej na obszarze Pasma Jałowieckiego i Grupy Mędralowej. W celu weryfikacji dokładności danych pozyskanych z LiDAR i identyfikacji form punktowych oprócz interpretacji modelu przeprowadzono kartowanie terenowe $\mathrm{z}$ użyciem GPS. Zaprezentowana w artykule metoda badań pozwala na zidentyfikowanie linii okopów rozmieszczonych na rozległym, często trudno dostępnym obszarze, przez co wskazana jest do stosowania podczas prowadzonych badań na obszarze Karpat.
\end{abstract}

Słowa kluczowe: fortyfikacje, okopy, II wojna światowa, LiDAR, Karpaty.

\section{Wprowadzenie}

Ziemne umocnienia polowe takie, jak okopy czy stanowiska strzeleckie są niewielkimi formami antropogenicznymi rzeźby terenu, które widoczne są na zobrazowaniach teledetekcyjnych o bardzo wysokiej szczegółowości takich, jak modele terenu wygenerowane z chmury punktów LiDAR (ang. Light Detection And Ranging). Ich kształt i stopień zachowania w krajobrazie zależy w dużej mierze od stopnia ich zaplanowania i zbudowania, a także zniszczenia (w wyniku działań wojennych), charakteru podłoża, sposobu późniejszego użytkowania terenu oraz oddziaływania procesów naturalnych (m.in. procesy stokowe: spełzywanie, spłukiwanie, osuwanie). Wysokim stopniem zachowania się tych form często cechują się odcinki położone w miejscach trudno dostępnych, zalesionych lub porzuconych gospodarczo. 
Lotniczy skaning laserowy wywodzący się z prowadzonych w latach 70 . $\mathrm{XX}$ wieku testów wojskowych jest metodą, której produkty znalazły zastosowanie $\mathrm{w}$ wielu dziedzinach nauki i gospodarki m.in. w leśnictwie, archeologii, hydrologii, geomorfologii, budownictwie czy energetyce (Sołoduchin i in. 1977; Nelson i in. 1984; Maclean, Krabill 1986; Banaszek 2014). Upowszechnienie się w ciągu ostatnich lat dostępu do danych LiDAR stworzyło nowe możliwości badawcze $\mathrm{w}$ archeologii. Wykorzystanie danych LiDAR pozwala na precyzyjne wykonywanie pomiarów znanych obiektów archeologicznych bądź identyfikację lokalizacji nowych stanowisk. Metoda ta umożliwia szczegółowe odwzorowanie topografii obiektów położonych $\mathrm{w}$ lesie czy w trudno dostępnych obszarach górskich. Metoda ta stała się ważnym sposobem badań dziedzictwa kulturowego, zwłaszcza na obszarach leśnych (Sztampke 2014). Pierwsze ukazujące się w literaturze publikacje dotyczyły budowy i działania urządzeń zastosowanych w lotniczym skaningu laserowym (Ackermann 1999; Wehr, Lohr 1999; Hug i in. 2004). Wykorzystanie produktów LiDAR po raz pierwszy na obszarze Polski zaprezentowano podczas warsztatów NATO odbywających się w 2000 roku w Lesznie (Holden i in. 2002). W tym samym czasie w wielu krajach na świecie panował bardzo szybki rozwój wykorzystania produktów LiDAR w badaniach archeologicznych (m.in. Shell, Roughley 2004; Sittler 2004; Devereux i in. 2005; Challis 2006). Badania te przyczyniły się do utworzenia w wielu krajach dużych programów badawczych skierowanych na ogólnokrajowe identyfikacje zasobów dziedzictwa kulturowego za pomocą danych LiDAR (Banaszek 2014). W Polsce wykorzystanie danych $\mathrm{z}$ lotniczego skaningu laserowego $\mathrm{w}$ archeologii rozpowszechniło się z końcem pierwszej dekady XXI wieku (w 2008 roku), a możliwości jego wykorzystania zaprezentowali m.in. Ł. Sławik i R. Zapłata (2010). Od tego czasu produkty LiDAR wykorzystano w archeologii w Polsce m.in. w pracach prowadzonych wokół Kętrzyna, Lasu Muszkowickiego, Krzemionek Opatowskich, na Suwalszczyźnie, Ziemi Lubuskiej, rejonie Smoszewa oraz wokół Sławna i Polanowa (za: Banaszek 2014). W ujęciu regionalnym dane LiDAR wykorzystane zostały podczas dokumentacji obiektów archeologicznych w województwie świętokrzyskim (Sztampke 2014). Ponadto metodę tę wykorzystano do zidentyfikowania osiedli z epoki brązu i epoki żelaza na Śląsku (Furmanek i in. 2015) czy też podczas badań średniowiecznych fortyfikacji obronnych Księstwa Biskupów Wrocławskich (Legut-Pintal 2012). Dane pochodzące z LiDAR-u wykorzystano również $w$ identyfikacji linii umocnień $z$ okresu II wojny światowej (Szady, Zapłata 2014; Franczak, Jucha 2015).

W niniejszym artykule dokonano interpretacji numerycznego modelu terenu uzyskanego $\mathrm{z}$ danych LiDAR w celu odtworzenia przebiegu linii okopów powstałej podczas II wojny światowej. W tym celu wybrano fragment linii zbudowanej na potrzeby armii niemieckiej w Paśmie Jałowieckim, znajdującym się w powiecie suskim (woj. małopolskie). W tekście przytoczono także kontekst historyczny powstania tychże form. 


\section{Cel badań}

Głównym celem postawionym przed artykułem jest sprawdzenie możliwości wykorzystania modeli terenu pochodzących z danych LiDAR do odtworzenia elementów historycznych fortyfikacji polowych. Aby zrealizować postawiony cel główny dokonano, oprócz interpretacji modelu, także kartowania terenowego z użyciem GPS w celu porównania możliwości odczytania informacji z LiDAR. Dlatego pierwszym celem pobocznym artykułu jest porównanie tych dwóch metod pozyskania danych. W czasie pomiaru terenowego dokonano także dokumentacji fotograficznej, z pomocą której zilustrowano artykuł. $Z$ uwagi na charakter przedmiotu badań, drugim celem dodatkowym jest zachowanie pamięci o trudzie oraz poświęceniu tych, którzy zostali zmuszeni do wykonania okopów w Paśmie Jałowieckim - ludności wsi Skawica, Zawoja oraz Grzechynia.

\section{Obszar badań}

Badaniem objęto teren Pasma Jałowieckiego i Grupy Mędralowej, znajdujących się w południowej Polsce, w województwie małopolskim, w powiecie suskim. Badany obszar znajduje się ok. $55 \mathrm{~km}$ na południowy zachód od Krakowa (ryc. 1A).

Pasmo Jałowieckie wraz z Grupą Mędralowej i Pasmem Solnisk bywa również nazywane ogólnie Pasmem Przedbabiogórskim (Figiel i in. 2006; Kondracki 2009). Badany obszar sąsiaduje od południa z masywem Babiej Góry (ryc. 1B). Najwyższym szczytem Pasma Jałowieckiego jest Jałowiec (1111 m n.p.m.), któremu pasmo zawdzięcza nazwę, natomiast najwyższym szczytem badanego obszaru jest Mędralowa (1169 m n.p.m.), nazywana również Wielkim Jałowcem. W podziale J. Kondrackiego (2009) badany obszar zaliczany jest do Beskidu Makowskiego, z kolei w nowszym podziale wykonanym w ośrodku krakowskim obszar ten zaliczany jest do Beskidu Żywiecko-Orawskiego (Balon, Jodłowski 2005). Na ryc. 1. połączono obszar badań na tle obu jednostek fizycznogeograficznych.

Fragment linii okopów OKH Stellung b1 nawiązuje do przebiegu głównego grzbietu Pasma Jałowieckiego. Najdłuższy odcinek został zachowany w jego części północno-wschodniej, na stokach Malikowskiego Gronia (760 m n.p.m.). Dlatego to w nim poddano kartowaniu dwa duże odcinki linii umocnień (obszary badań I i II). Obszar badań nr III wyznaczono w północno-wschodniej, najwyżej wyniesionej części Grupy Mędralowej, na stokach Mędralowej (Wielki Jałowiec) (1169 m n.p.m.) i Kolistego Gronia (Magurka) (1114 m n.p.m.). Ponadto na fragmencie obszaru badań I i III dokonano kontrolnego kartowania terenowego w celu uzyskania danych porównawczych. 


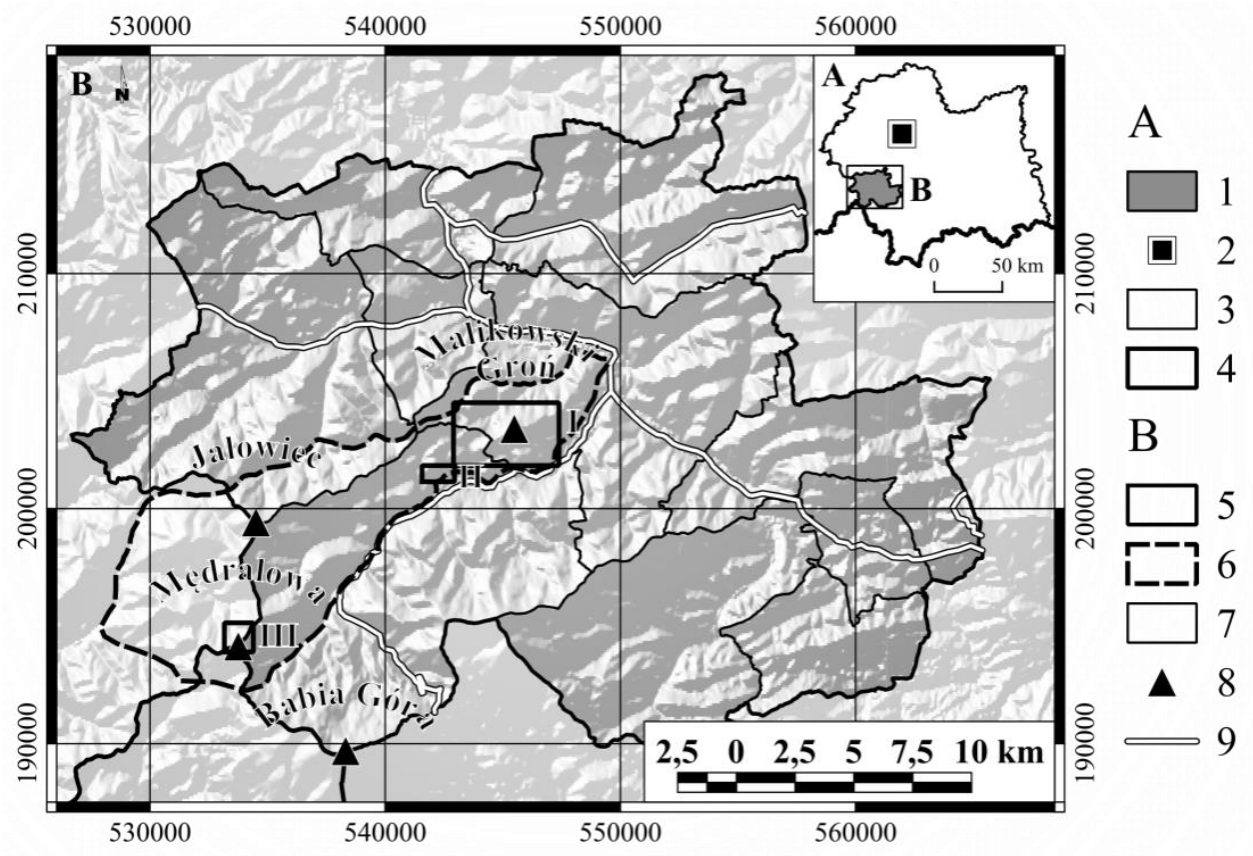

Ryc. 1. Lokalizacja obszaru badań na tle modelu cieniowanego SRTM

Objaśnienia: Mapa A: 1 - powiat suski, 2 - miasto Kraków, 3 - granica województwa małopolskiego, 4 - granica państwa; Mapa B: 5 - położenie obszarów badań (I, II, III),

6 - obszar Pasma Jałowieckiego i grupy Mędralowej, 7 - granice gmin, 8 - szczyty górskie wymienione w artykule, 9 - ważniejsze drogi

Źródło: opracowanie własne

\section{Historia powstania umocnień}

Zachowane do dnia dzisiejszego ślady umocnień obronnych w Beskidach powstawały w dwóch etapach. Część z nich została wykonana jeszcze przed wybuchem II wojny światowej w 1939 roku, jednak większość z nich powstała pod koniec trwania wojny.

Etap pierwszy był związany z fortyfikacją pasa przygranicznego Polski ze Słowacją w 1939 roku, kiedy rozpoczęto budowę linii umocnień w odległości 15-20 km od granicy na potrzeby Wojska Polskiego (Steblik 1989; Sadowski 2009, 2011; Franczak, Jucha 2015). Do działań tych przystąpiono jednak dopiero latem i jesienią 1939 roku, w związku z czym fortyfikacje nie zostały ukończone do wybuchu wojny (Suchanek 2004; Kastelik i in. 2013). Powstałe umocnienia utworzyły odcinek obrony „Zawoja - Maków”, wchodzący w skład większego odcinka „Żywiec” (Suchanek 2004; Bednarz, Sadowski 2009; Sadowski 2011). Nieliczne obiekty znajdowały się wzdłuż linii obrony wyznaczonej od Hali 
Kamieńskiego poprzez Przełęcz Lipnicką po Sidziny, natomiast pojedyncze stanowiska obronne wykonano na tyłach głównej linii obrony w dolinie Skawicy (Mydlarz 2009; Franczak, Jucha 2015). Na obszarze Pasma Jałowieckiego umiejscowione zostały m.in. na Sitkowej Grapie, w miejscu znacznego zwężenia dna doliny Skawicy (Franczak, Jucha 2015) oraz tuż przy granicy państwowej na rozciągających się na głównym grzbiecie pasma Halach: Kamińskiego i Mędralowej (Śledziński 2009; Mydlarz 2009).

Drugi etap budowy fortyfikacji obronnych w Paśmie Jałowieckim związany był ze zbliżeniem się do granic Rzeszy wojsk radzieckich. Wówczas Niemcy przystąpili do budowy - głównie na terytorium okupowanej Polski - kilku linii umocnień, mających za zadanie umożliwić powstrzymanie nacierających Sowietów ze wschodu. Prace rozpoczęto w 1944 roku, a ich wynikiem był system linii umocnień polowych biegnących z północy na południe przez całą Europę Środkową, od Morza Bałtyckiego aż po dolinę Dunaju (Rawski 1966; Sadowski 2009). Linie te nosiły niemiecką nazwę Oberkommando des Heeres Stellungen - w skrócie OKH Stellungen. Z kolei nazwy poszczególnych linii składały się z litery i numeru porządkowego. W przypadku fortyfikacji przebiegających w pobliżu Zawoi i Skawicy była to linia OKH Stellung b1 (Śledziński 2009; Rosiek 2014).

Większość budowanego w 1944 roku systemu fortyfikacji stworzono od podstaw, jednak na krótkich odcinkach w jej skład włączana była infrastruktura obronna wybudowana przez Wojsko Polskie w 1939 roku. Linia OKH Stellung b1 na badanym obszarze nie została wykorzystana w działaniach wojennych, ponieważ Niemcy wycofali się w kierunku Koszarawy i dalej na Żywiecczyznę przed nadejściem frontu. Armia Czerwona zajęła bez walki tereny pasma Jałowieckiego w styczniu 1945 roku (Kantyka 1985).

\subsection{Przebieg pozycji OKH Stellung b1 na badanym obszarze}

Linia OKH Stellung b1 prowadziła na obszarze Pasma Jałowieckiego z północy przez Grzechynię w kierunku kulminacji Malikowskiego Gronia (760 m n.p.m.), na którym skręcała i przyjmowała przebieg w kierunku południowo-zachodnim. $\mathrm{Na}$ dalszym odcinku Zawoję Przysłop linia umocnień prowadziła do Zawoi Wełczy, z której wznosiła się w kierunku ostatnich umocnień na terytorium Polski, mieszczących się na szczycie Mędralowej (Sadowski 2011; Franczak, Jucha 2015). Następnie linia schodziła do Orawskiej Półgóry (Oravská Polhora) i prowadziła dalej na południe.

Na obszarze Pasma Jałowieckiego, oprócz linii obrony przeciwpiechotnej, funkcjonowały także punkty oporu, które miały za zadanie niszczyć broń pancerną przeciwnika. Według M. Śledzińskiego (2009) na obszarze pasma znajdowały się dwa stanowiska tego typu: w Grzechynii i na Hali Kamińskiego. Jednak interpretacja numerycznego modelu terenu LiDAR oraz badania terenowe autorów wykazały istnienie także trzeciego punktu oporu zlokalizowanego na Hali 
Mędralowej. Punkt obrony w Grzechyni miał za zadanie bronić drogi i linii kolejowej w dolinie Skawy w okolicy Makowa Podhalańskiego. Z kolei punkty obrony na halach: Kamińskiego i Mędralowej zostały zlokalizowane w partiach szczytowych, tuż przy granicy państwowej.

\section{Materiały i metodyka}

Z uwagi na użycie dwóch metod, niniejszy podrozdział został podzielony na dwie części: pierwszą, dotyczącą sposobu odtworzenia przebiegu okopów na podstawie danych LiDAR, drugą, dotyczącą sposobu przeprowadzenia pomiaru i zebrania materiału w terenie, zawierającą dokumentację zdjęciową prezentującą wygląd obiektów w terenie. Opis i porównanie metod użytych w artykule były przedmiotem rozważań artykułu autorów (Franczak, Jucha 2015), w którym wskazano ich mocne i słabe strony na przykładzie niewielkiego fragmentu zbadanego obydwoma sposobami. Wyciągnięte wnioski przeniesiono w niniejszym tekście na większy obszar badawczy.

\subsection{Prace w GIS z użyciem danych LiDAR}

Do odtworzenia przebiegu linii użyto numerycznego modelu terenu wygenerowanego z chmury punktów LiDAR, udostępnionego przez Centralny Ośrodek Dokumentacji Geodezyjnej i Kartograficznej dla Instytutu Geografii i Gospodarki Przestrzennej Uniwersytetu Jagiellońskiego. Rozmiar komórki rastra modelu wynosił 1x1 m. Model przekształcono do formatu ASCII grid w programie FUSION/LDV 3.42 (FUSION/LDV: Software for LiDAR data and visualisation - http://forsys. cfr.washington.edu/fusion/). Następnie zaimportowano go do programu Quantum GIS 2.8.1. (Quantum GIS Project, - http://qgis.org/). W programie tym gridy poddano obróbce w następujący sposób:

- połączono poszczególne fragmenty w jeden model (funkcja złączenie rastrów);

- wygenerowano model cieniowany (shaded relief); wykonano trzy warianty o różnym azymucie i kącie oświetlenia (ryc. $2 \mathrm{~A}-\mathrm{C}$ );

- powstałe mapy poddano wektoryzacji; utworzono dwie warstwy wektorowe: liniową zawierającą przebieg linii okopów w podziale na cztery klasy (rów okopu, rów łącznikowy, rów dobiegowy do schronu biernego, rów dobiegowy do stanowiska strzeleckiego), punktową zawierającą stanowiska punktowe w podziale na trzy klasy: schron bierny, schron bez rowu dobiegowego, stanowisko strzeleckie (ryc. 2D). 

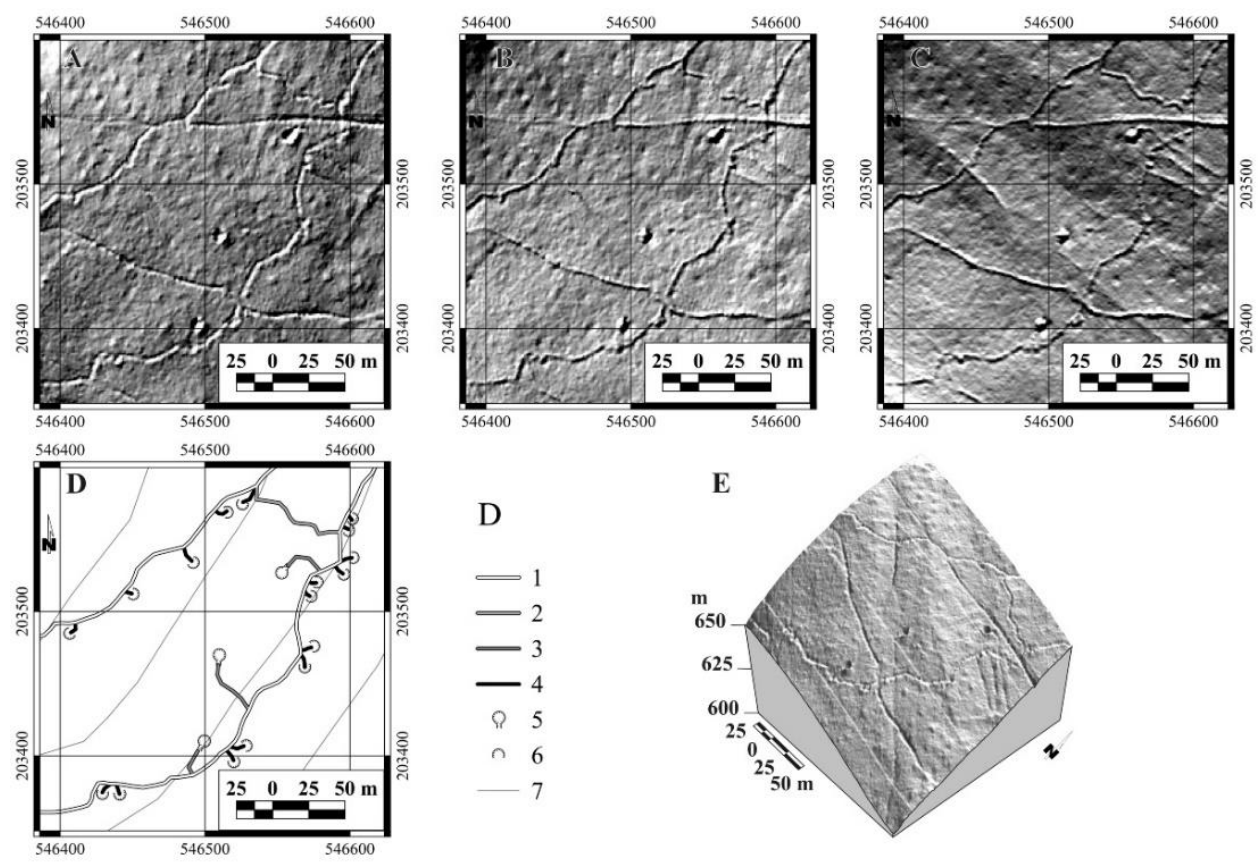

Ryc. 2. Numeryczny model terenu fragmentu linii okopów

w pobliżu szczytu Malikowski Groń

Użyte podczas interpretacji warianty cieniowania: A - azymut $315^{\circ}$, kąt $45^{\circ}$, $\mathrm{B}$ - azymut $135^{\circ}$, kąt $60^{\circ}, \mathrm{C}$ - azymut $180^{\circ}$, kąt $90^{\circ}, \mathrm{D}$ - mapa okopów (wynik wektoryzacji): 1 - główna linia okopu, 2 - rów łącznikowy, 3 - rów dobiegowy do schronu, 4 - rów dobiegowy do stanowiska strzeleckiego, 5 - schron bierny $\mathrm{z}$ rowem dobiegowym, 6 - stanowisko strzeleckie, 7 - poziomice (cięcie co $10 \mathrm{~m}$ ); E - blokdiagram przedstawionego fragmentu

Źródło: opracowanie własne

Wykorzystanie trzech wariantów oświetlenia modelu cieniowanego umożliwiło łatwiejsze wyszukiwanie form terenu towarzyszących linii okopów, w szczególności krótkich rowów dobiegowych i stanowisk strzeleckich, a także przebiegu w obszarach o zróżnicowanym ukształtowaniu i ekspozycji terenu. Wariant pierwszy (ryc. 2A) jest najpowszechniej wykorzystywanym z racji tego, że formy wklęsłe i wypukłe są przy jego użyciu postrzegane z właściwą percepcją (Medyńska-Gulij 2011). W przypadku drugiego (ryc. 2B), obiekty o ukształtowaniu wklęsłym (np. rowy) są postrzegane jako wypukłe (jako wały lub nasypy). Wariant trzeci (ryc. 2C) w szczególny sposób uwidacznia formy płytkie - jak przypadek jednego z obiektów liniowych opisany poniżej.

Na przedstawionym fragmencie (ryc. 2) widoczne są, oprócz linii umocnień, także inne liniowe formy terenu. W osi wschód-zachód przebiegają dwie drogi leśne, widoczne na ryc. 2A, 2B i 2C. Różnią się one od okopów przez ich zbliżony 
do prostoliniowego charakter, większą głębokość i szerokość. Umocnienia ziemne są lepiej odróżnialne zwłaszcza w szerszym polu widzenia niż przedstawione na ryc. 2. Oprócz dwóch wymienionych dróg jest widoczny także drugi, płytki obiekt o charakterze prostoliniowym, przebiegający w poprzek linii okopów (ryc. 2C). Może to być pozostałość po dawnej drodze lub fragment wcześniejszej, polskiej fortyfikacji z 1939 roku (linia kontynuuje się i schodzi w dolinę Skawicy). Widoczne na blokdiagramie (ryc. 2E) trzy proste linie zagłębień prostopadłe do kierunku północy są prawdopodobnie artefaktem modelu, powstałym w momencie tworzenia chmury punktów LiDAR.

\subsection{Kartowanie terenowe $\mathrm{z}$ użyciem GPS}

Na potrzeby badania dokonano dwóch kartowań: pierwsze odbyło się w terminie 12.09.2014 i objęło fragment ok. 0,5 km linii okopu na stoku Malikowskiego Gronia (760 m n.p.m.); drugiego dokonano 14.08.2015 w obrębie punktu oporu wokół szczytu Mędralowej (1169 m n.p.m.) i objęło fragment ok. 2,0 km linii okopu. W obu przypadkach badanie przeprowadzono w następujący sposób:

1) Podczas badania użyto odbiornika Garmin GPSMap 62; dokładność pomiaru $\mathrm{w}$ dniach pomiaru wynosiła 6-8 $\mathrm{m}$ w terenie (informacja $\mathrm{z}$ odbiornika); użyto funkcji zapisu śladu (co 10 sekund), w celu uzyskania przebiegu linii oraz zapisu punktów orientacyjnych (waypointów) przy stanowiskach punktowych i miejscach zmian charakteru okopu (np. połączenie rowu głównego z rowem dobiegowym);

2) Otrzymane warstwy gpx zapisane w terenie przetworzono w programie Quantum GIS w następujący sposób:

a) zaimportowano warstwy gpx do programu;

b) warstwę punktów orientacyjnych (waypointów) podzielono na trzy warstwy punktowe:

- „obiekty” - warstwa zawierająca stanowiska oznaczone i sklasyfikowane podczas pomiaru terenowego (tab. 1, pkt. 2-4);

- „odgałęzienia” - warstwa zawierająca waypointy zaznaczone przez autorów w terenie mające ułatwić orientację podczas przenoszenia śladu GPS, np. połączenia rowów;

- ,pozostałe” - warstwa zawierająca waypointy, takie jak początek/koniec pomiaru itp.;

c) utworzono warstwę liniową zawierającą przebieg okopu ze śladu GPS, dzieląc ją na odcinki sklasyfikowane analogicznie do warstwy liniowej pochodzącej z LiDAR; podczas przenoszenia śladu GPS na warstwę dokonano usunięcia zbędnych odcinków (np. podwójne ślady w sytuacji, gdy autorzy doszli rowem dobiegowym do stanowiska punktowego i wracali do głównej linii okopu). 
Obiekty sklasyfikowane podczas pomiaru terenowego w dniach 12.09.2014 i 14.08.2015

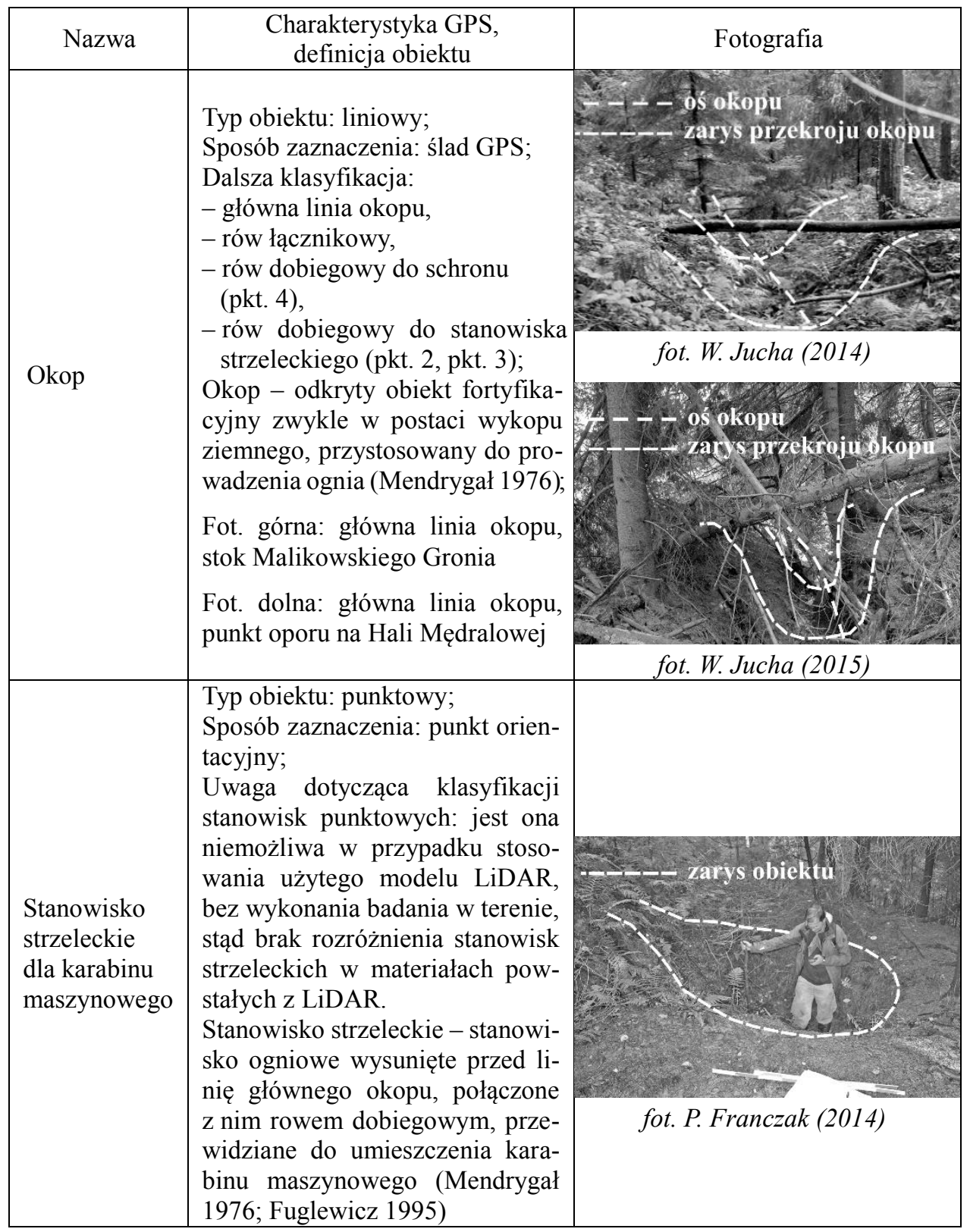


Tabela 1 (cd.)

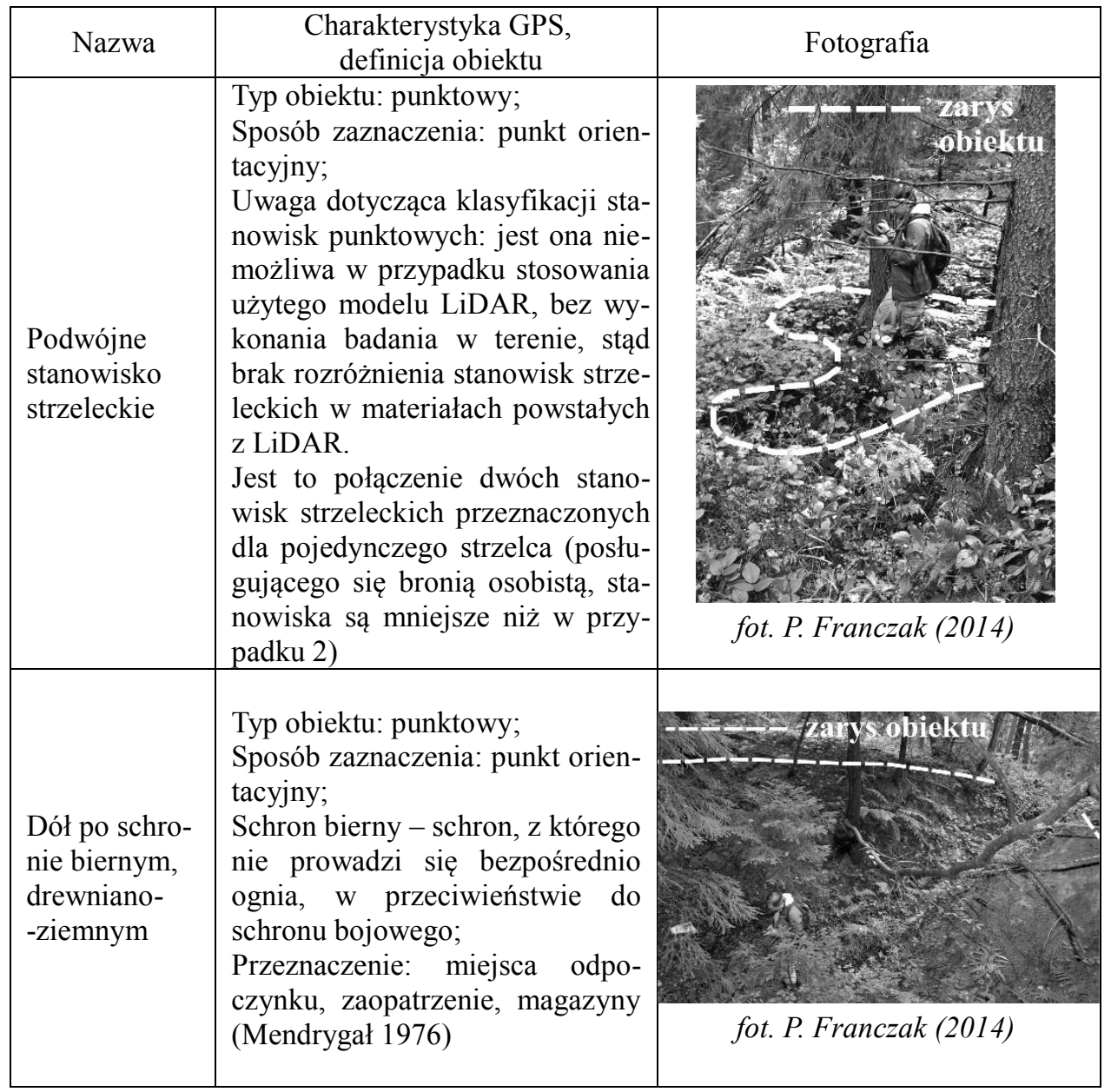

Źródło: P. Franczak, W. Jucha (2015), zmodyfikowane.

W rezultacie wykonania opisanych czynności powstały po cztery warstwy wynikowe w GIS dla obszarów badań I i III: warstwa liniowa i punktowa powstała w wyniku kartowania terenowego i warstwy analogiczne powstałe w wyniku interpretacji numerycznego modelu terenu. Dla obszaru II, nieobjętego badaniem terenowym, powstały tylko warstwy na podstawie interpretacji materiałów LiDAR.

\section{Wyniki badań}

W Paśmie Jałowieckim i Grupie Mędralowej wyznaczono trzy obszary badań. Wydzielenia dokonano na podstawie stanu zachowania (na badanych obszarach zachowały się one w szczególnie dobrym stanie, czytelnie odwzorowując się na 
modelu LiDAR). Pomiędzy nimi występują także wyraźne różnice charakteru okopów, które przedstawiono poniżej:

\section{Odcinek na stokach Malikowskiego Gronia}

Jest to największy zachowany fragment okopów, zawierający w pełni przygotowaną, podwójną linię terenowych umocnień połączonych rowami łącznikowymi, przebiegającą na zachód od wsi Białka k. Makowa Podhalańskiego i Skawica (ryc. 3A). Na tym obszarze dokonano kontrolnego badania terenowego, w czasie którego dokonano szczegółowej klasyfikacji stanowisk strzeleckich (ryc. 3B i 3C). Długość zbadanego odcinka wynosi ok. $6 \mathrm{~km} \mathrm{w}$ terenie.

Obszar przedstawiony na rycinie jest obecnie w znacznej mierze zalesiony. Obszary nieleśne, użytkowane rolniczo lub odłogowane, znajdują się w południowo-zachodniej części terenu badań. Tam też użyto dodatkowej podklasy „przebieg okopu domniemany", z racji na znaczne zatarcie formy na modelu terenu.

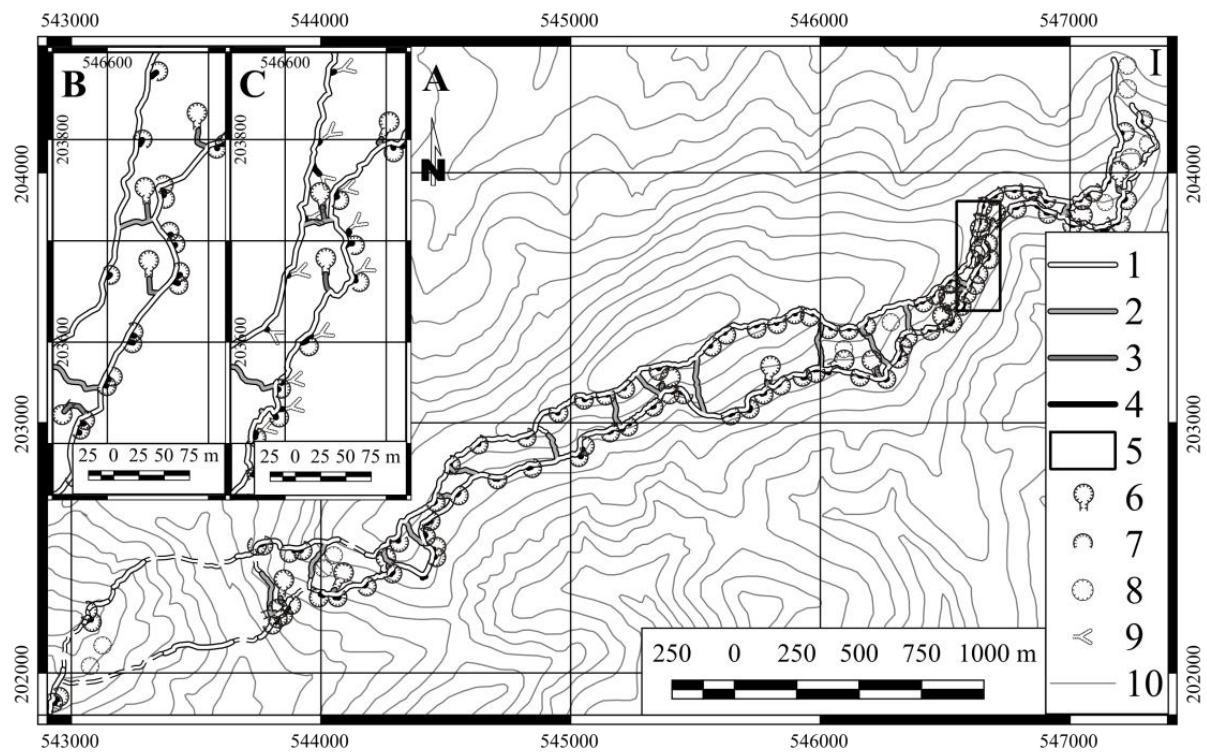

Ryc. 3. Obszar badań nr I: Mapa A - przebieg linii okopu, Mapa B i C - fragment linii zbadany przy użyciu danych LiDAR (B) i GPS (C)

Objaśnienia: 1 - główna linia okopu (linia przerywana - odcinek o przebiegu domniemanym), 2 - rów łącznikowy, 3 - rów dobiegowy do schronu, 4 - rów dobiegowy do stanowiska strzeleckiego, 5 - zasięg map B i C, 6 - Schron bierny z rowem dobiegowym, 7 - stanowisko strzeleckie, 8 - stanowisko ziemne bez rowu dobiegowego; 9 - podwójne stanowisko strzeleckie (tylko mapa C), 10 - poziomice (cięcie co $20 \mathrm{~m}$ ) Źródło: opracowanie własne

\section{Odcinek pomiędzy wioskami Skawica i Zawoja}

Okop przebiegający na południowy zachód od fragmentu I zmienia swój charakter (ryc. 4). Na tym obszarze powstała jedna linia umocnień - w zachodniej 
części, w dolinie potoku Kalinka, którą biegnie droga łącząca Zawoję ze Stryszawą, rów ma przebieg zygzakowaty, a zinwentaryzowany odcinek mierzy około $1,5 \mathrm{~km}$ długości. Wzdłuż rowu zachowała się znacznie mniejsza liczba stanowisk strzelniczych niż na pozostałych dwóch obszarach badawczych.

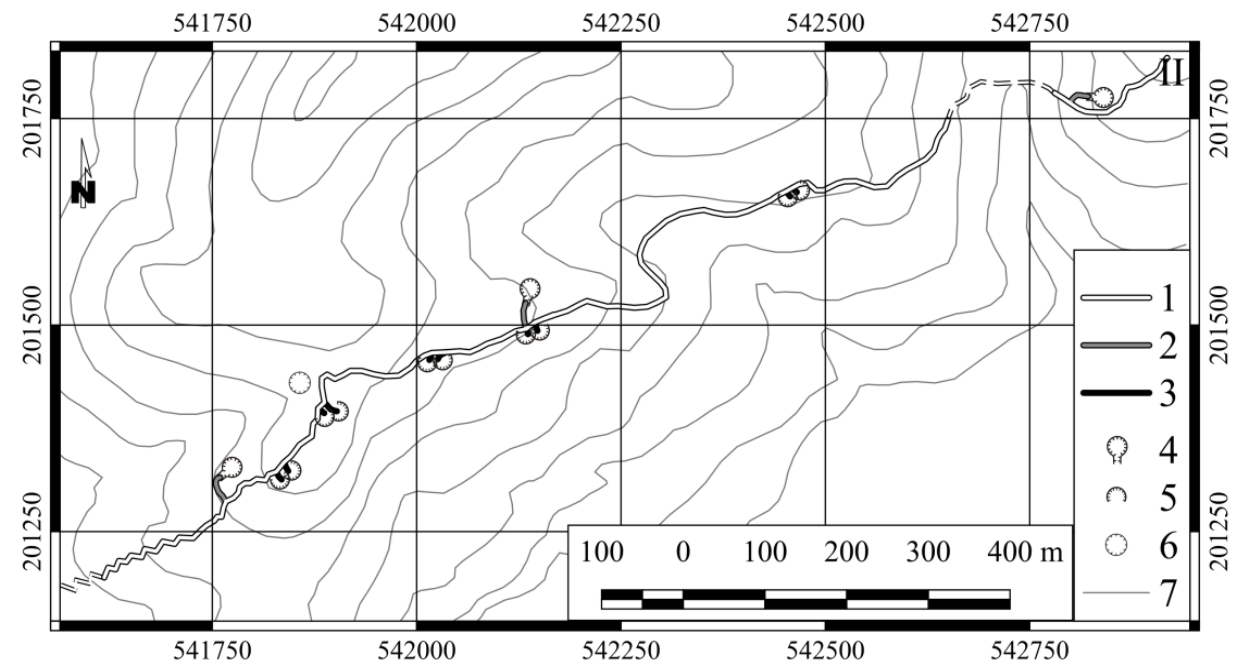

Ryc. 4. Obszar badań nr II: 1 - główna linia okopu (linia przerywana - odcinek o przebiegu domniemanym), 2 - rów dobiegowy do schronu, 3 - rów dobiegowy do stanowiska strzeleckiego, 4 - schron bierny z rowem dobiegowym, 5 - stanowisko strzeleckie, 6 - stanowisko ziemne bez rowu dobiegowego, 7 - poziomice (cięcie co $20 \mathrm{~m}$ )

Źródło: opracowanie własne

\section{Punkty oporu na Halach Kamińskiego i Mędralowej}

Punkty oporu mają charakter zamkniętych pętli wokół szczytów, zbudowanych $\mathrm{z}$ okopów połączonych przebiegającymi w poprzek grzbietów rowami łącznikowymi (ryc. 5). Szczegółowo został zbadany w terenie punkt oporu na Hali Mędralowej (położony w południowej części obszaru badań). Ten punkt oporu prawdopodobnie nie był dokończony - jeden z odcinków łącznikowych jest ślepo zakończony, a także istnieje ślad po rozpoczętej linii biegnącej wzdłuż grzbietu we wschodniej części tego punktu oporu. Punktu oporu na Hali Kamińskiego (w północnej części obszaru badań nr III) nie poddano szczegółowej analizie, ponieważ nie udało się podczas interpretacji modelu LiDAR rozpoznać żadnych obiektów punktowych, ani rowów dobiegowych. 

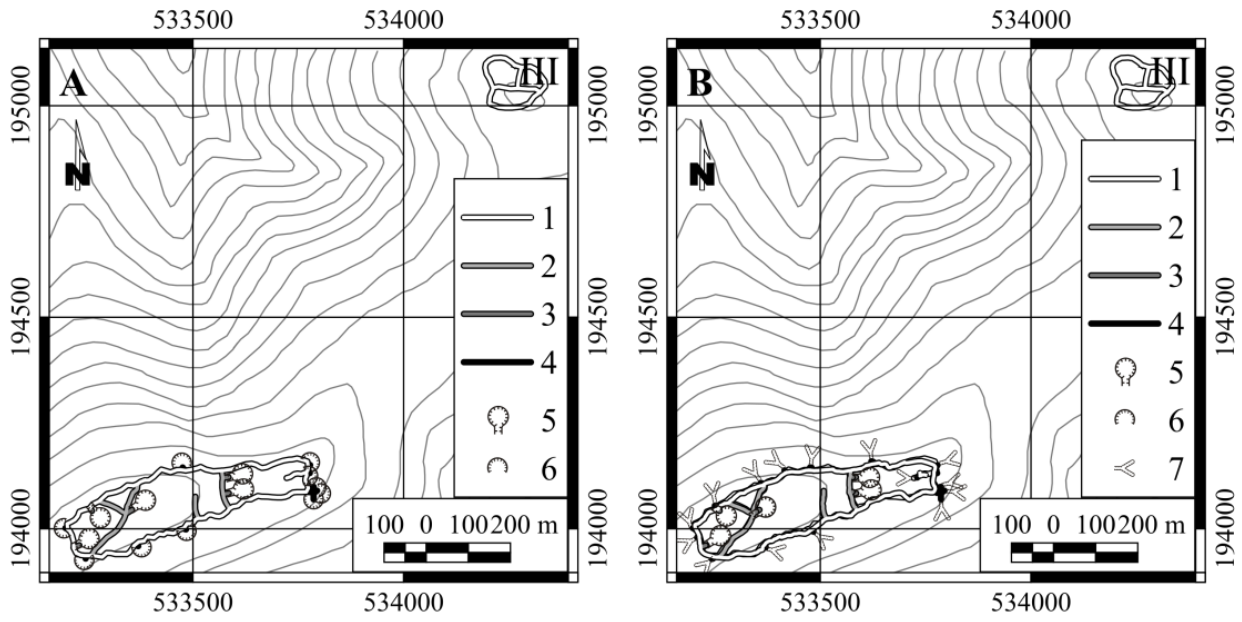

Ryc. 5. Obszar badań nr III: Mapa A - dane pochodzące z LiDAR, Mapa B - dane pochodzące $\mathrm{z}$ kartowania terenowego z GPS

Objaśnienia: 1 - główna linia okopu, 2 - rów łącznikowy, 3 - rów dobiegowy do schronu biernego, 4 - rów dobiegowy do stanowiska strzeleckiego, 5 - Schron bierny z rowem dobiegowym, 6 - stanowisko strzeleckie, 7 - podwójne stanowisko strzeleckie (Mapa B)

Źródło: opracowanie własne

\section{Analiza wyników badań}

Zbadane fortyfikacje polowe miały łączną długość ponad $21 \mathrm{~km}, \mathrm{z}$ czego ponad $16 \mathrm{~km}$ przypadało na odcinek przedstawiony na I obszarze badań (tab. 2). Użyte w badaniu fragmenty charakteryzowały się dość dobrym stopniem zachowania odcinków o niepewnym przebiegu lub zatartych w rzeźbie terenu było łącznie $1554 \mathrm{~m}$, czyli $14,1 \%$ całości. Były to odcinki przebiegające w terenie niezalesionym, na którym zaznaczały się ślady użytkowania rolniczego w postaci m.in. dróg polnych prowadzących do pól uprawnych. W takich przypadkach domniemany przebieg linii okopu wyznaczano łącząc sąsiadujące odcinki zgodnie z odniesieniem do nachylenia i ekspozycji stoku (ryc. 3). Nie odtwarzano w tych miejscach form punktowych, takich jak stanowiska strzeleckie czy doły po schronach biernych.

Istotną z punktu widzenia metodycznego informacją jest, czy wszystkie elementy infrastruktury towarzyszącej liniom okopów uda się odczytać używając wyłącznie danych LiDAR. Ma to znaczenie szczególnie w przypadku znacznej uciążliwości oraz małej dokładności pomiaru terenowego. W tab. 3. zawarto zestawienie parametrów obu wykonanych pomiarów $\mathrm{z}$ danymi pochodzącymi $\mathrm{z}$ interpretacji LiDAR. 
Tabela 2

Parametry wektorowych obiektów liniowych zaznaczonych przy interpretacji danych LiDAR

\begin{tabular}{|c|c|c|c|}
\hline Rodzaj & Liczba obiektów & $\begin{array}{c}\text { Długość łączna } \\
(\mathrm{m})\end{array}$ & $\begin{array}{c}\begin{array}{c}\text { Długość średnia } \\
(\mathrm{m})\end{array} \\
\end{array}$ \\
\hline \multicolumn{4}{|c|}{ I. Odcinek na stokach Malikowskiego Gronia } \\
\hline $\begin{array}{l}\text { Główna linia okopu } \\
\text { (dolna) }\end{array}$ & 1 & 5570 & (nie dotyczy) \\
\hline $\begin{array}{l}\text { Główna linia okopu } \\
\text { (górna) }\end{array}$ & 1 & 5348 & (nie dotyczy) \\
\hline $\begin{array}{l}\text { Odcinek } \\
\text { o przebiegu } \\
\text { domniemanym }\end{array}$ & $\begin{array}{c}12 \text { (łączna liczba } \\
\text { odcinków) }\end{array}$ & 1318 & 109,8 \\
\hline $\begin{array}{l}\text { Odcinek } \\
\text { lącznikowy }\end{array}$ & 16 & 2183 & 136,0 \\
\hline $\begin{array}{l}\text { Rów dobiegowy do } \\
\text { schronu biernego }\end{array}$ & 20 & 484 & 24,2 \\
\hline $\begin{array}{l}\text { Rów dobiegowy } \\
\text { do stanowiska } \\
\text { strzeleckiego }\end{array}$ & 135 & 1245 & 9,2 \\
\hline \multicolumn{4}{|c|}{ II. Odcinek pomiędzy Skawicą a Zawoją } \\
\hline Główna linia okopu & 1 & 1601 & (nie dotyczy) \\
\hline $\begin{array}{l}\text { Odcinek } \\
\text { o przebiegu } \\
\text { domniemanym }\end{array}$ & $\begin{array}{c}2 \text { (łączna liczba } \\
\text { odcinków) }\end{array}$ & 236 & 118,0 \\
\hline $\begin{array}{l}\text { Rów dobiegowy do } \\
\text { schronu biernego }\end{array}$ & 3 & 76 & 25,3 \\
\hline $\begin{array}{l}\text { Rów dobiegowy } \\
\text { do stanowiska } \\
\text { strzeleckiego }\end{array}$ & 10 & 109 & 10,9 \\
\hline \multicolumn{4}{|c|}{ III. Punkty oporu na Halach Kamińskiego i Mędralowej } \\
\hline $\begin{array}{l}\text { Okop na Hali } \\
\text { Kamińskiego } \\
\end{array}$ & 1 & 934 & (nie dotyczy) \\
\hline $\begin{array}{l}\text { Główna linia } \\
\text { okopu na Hali } \\
\text { Mędralowej }\end{array}$ & 1 & 1392 & (nie dotyczy) \\
\hline $\begin{array}{l}\text { Odcinek } \\
\text { łącznikowy }\end{array}$ & 5 & 478 & 95,6 \\
\hline $\begin{array}{l}\text { Rów dobiegowy do } \\
\text { schronu biernego }\end{array}$ & 5 & 68 & 13,6 \\
\hline $\begin{array}{l}\text { Rów dobiegowy } \\
\text { do stanowiska } \\
\text { strzeleckiego }\end{array}$ & 10 & 110 & 11,0 \\
\hline
\end{tabular}

Źródło: opracowanie własne. 
Porównanie parametrów z odcinków zbadanych z danych LiDAR i GPS

\begin{tabular}{|c|c|c|}
\hline Parametr & LiDAR & GPS \\
\hline \multicolumn{3}{|c|}{ I. Fragment odcinka na stokach Malikowskiego Gronia } \\
\hline Długość linii (m) & 1011 & 1004 \\
\hline $\begin{array}{l}\text { Liczba obiektów } \\
\text { punktowych }\end{array}$ & 24 & 26 \\
\hline $\begin{array}{l}\text { Różnice w obiektach } \\
\text { punktowych }\end{array}$ & $\begin{array}{l}+ \text { jeden dół po schronie } \\
\text { biernym }\end{array}$ & $\begin{array}{l}+ \text { jedno stanowisko na } \\
\text { górnej linii okopu; } \\
+ \text { dwa stanowiska na } \\
\text { dolnej linii okopu; } \\
\text { + klasyfikacja stanowisk } \\
\text { strzeleckich; }\end{array}$ \\
\hline \multicolumn{3}{|c|}{ II. Punkt oporu na Hali Mędralowej } \\
\hline Długość linii (m) & 2048 & 2039 \\
\hline $\begin{array}{l}\text { Liczba obiektów } \\
\text { punktowych }\end{array}$ & 18 & 22 \\
\hline $\begin{array}{l}\text { Różnice w obiektach } \\
\text { punktowych }\end{array}$ & - & $\begin{array}{l}\text { + cztery stanowiska } \\
\text { strzeleckie; } \\
+ \text { klasyfikacja stanowisk } \\
\text { strzeleckich; }\end{array}$ \\
\hline
\end{tabular}

Źródło: opracowanie własne.

W przypadku liniowych obiektów wektorowych pochodzących z interpretacji LiDAR, obserwowany jest bardziej wygładzony charakter oraz ich mniejsza krętość niż w przypadku śladów GPS. Widoczny jest przypadek znacznie krótszego odcinka i mniejszego kąta zakrętu do schronu biernego, znajdującego się w północnej części pierwszego obszaru (ryc. 3B). Zdarzają się również przypadki znacznego wydłużenia odcinka, niezgodnego z przebiegiem rzeczywistym, jak w przypadku ślepo zakończonego rowu w środkowej części punktu oporu na Hali Mędralowej (ryc. 5A i 5B). Obie opisane sytuacje często występują i powodują stosunkowo niewielką różnicę (rzędu kilku metrów) w przebiegu obu linii.

Podczas badania terenowego z GPS na stoku Malikowskiego Gronia pominięto jeden z dołów po schronie biernym, będący jedną z największych i najgłębszych form punktowych na tej fortyfikacji polowej (Franczak, Jucha 2015). Rów dobiegowy został w trakcie kartowania zaznaczony błędnie jako początek rowu łącznikowego. Można przy tym stwierdzić, że dla zbadanego fragmentu jest on położony nietypowo - ma on wejście umieszczone od północy, a jego rów dobiegowy zakręca w lewo. W przypadku pozostałych trzech zbadanych w terenie schronów biernych jest odwrotnie - rów dobiegowy zakręca w prawo, a wejście znajduje się od strony południowej (ryc. 3B). 
Odcinek na stoku Malikowskiego Gronia ma charakter podwójnej linii okopu połączonej rowami łącznikowymi (ryc. 3). W przypadku badanego odcinka, dla linii położonej po północno-zachodniej stronie, użyte będzie określenie „górna linia okopu" (jest ona położona wyżej na stoku), a w przypadku linii położonej po stronie południowo-wschodniej - „dolna linia okopu” (ryc. 6).

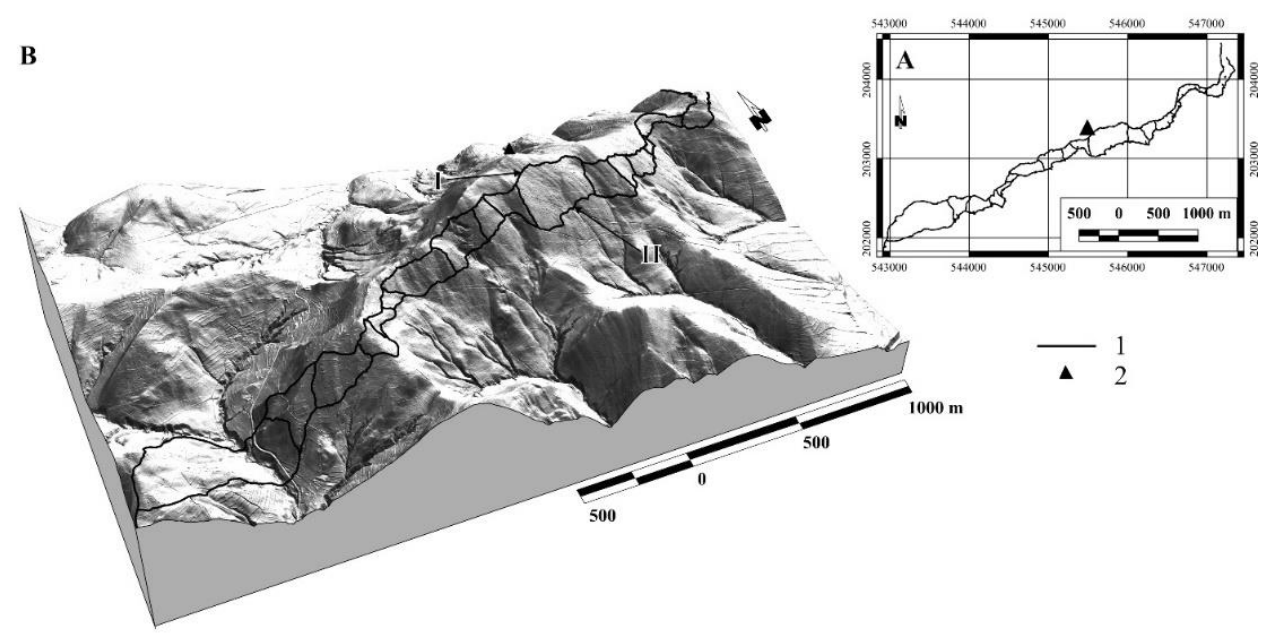

Ryc. 6. Przebieg linii okopów na obszarze badań nr I: Mapa A - mapa linii, Mapa B - blokdiagram. Objaśnienia: 1 - linia okopu, 2 - szczyt Malikowski Groń, I - górna linia okopu, II - dolna linia okopu Źródło: opracowanie własne

W przypadku badania $\mathrm{z}$ użyciem LiDAR pominięto trzy stanowiska strzeleckie. Powtórna analiza modelu umożliwiła lokalizację pominiętych wcześniej dwóch z nich, natomiast trzeciego nie udało się wskazać na modelu LiDAR (forma jest zbyt płytka, aby udało się ją odnaleźć na modelu). Nie udało się także na podstawie samego modelu przypisać stanowiskom strzeleckim klasyfikacji na stanowiska karabinów maszynowych i podwójne stanowiska strzeleckie. Na mapie powstałej z użyciem GPS można stwierdzić, że przy górnej linii okopów były zlokalizowane wyłącznie stanowiska podwójne dla strzelców (jest ich łącznie 35, rozmieszczonych co ok. $120 \mathrm{~m}$ ), natomiast na dolnej stanowiska były rozlokowane w parach: przy każdym stanowisku dla karabinu maszynowego od lewej strony (patrząc w spodziewanym kierunku natarcia) znajdowało się osłaniające je podwójne stanowisko dla strzelców. Schemat par stanowisk powtarza się w każdym miejscu na linii dolnej okopu, zatem ustaloną podczas badania terenowego klasyfikację można rozciągnąć na resztę linii dolnej. Łącznie jest ich 50 na całym zbadanym odcinku, rozmieszczonych co około $100 \mathrm{~m}$. 
Elementem nietypowym zaznaczającym się na modelu LiDAR są doły przypominające te przeznaczone na schrony bierne, wykopane wewnątrz obydwu linii, natomiast niepołączone z nimi rowami dobiegowymi. Jest ich łącznie 11, w tym cztery szczególnie się wyróżniające, gdyż znajdują się w pobliżu górnej, a nie dolnej linii (ryc. 2A). Być może ich powstanie nie jest związane $\mathrm{z}$ wykonaniem tej linii, natomiast wyraźny obraz ich na modelu LiDAR spowodował wydzielenie ich jako osobnej klasy obiektów do dalszego zbadania.

W przypadku Hali Mędralowej ponowne badanie terenowe umożliwiło zaklasyfikowanie stanowisk punktowych do typów występujących na obszarze badań, a także ujawniło dalsze cztery stanowiska, które zostały pominięte $\mathrm{w}$ trakcie prac kameralnych z LiDAR. W przypadku tych form, często płytkich i niewielkich, mogły nastąpić inne pominięcia, np. na odcinku od Skawicy do Zawoi w części środkowej i północno-wschodniej, gdzie znajduje się wyraźna przerwa pomiędzy stanowiskami strzeleckimi (ryc. 4).

\section{Dyskusja nad wynikami badań}

Odtworzony na obszarze Pasma Jałowieckiego i Grupy Mędralowej odcinek linii OKH Stellung b1 o łącznej długości $16160 \mathrm{~m}$ (główne linie okopów i linie punktów oporu) charakteryzuje się bardzo dobrym stanem zachowania. Ponadto na niemal całym badanym odcinku udało się udokumentować w bardzo dobrym stanie zachowania infrastrukturę obronną w postaci m.in. schronów biernych, stanowisk strzelniczych oraz rowów łącznikowych i dobiegowych. Jest to najdłuższy zachowany odcinek jaki udało się dotychczas udokumentować z użyciem interpretacji LiDAR na obszarze Polski. Przebieg innych równie długich fragmentów umocnień pochodzących z okresu II wojny światowej, jak np. odcinka prowadzącego w Beskidzie Makowskim od Stryszowa do Makowa Podhalańskiego na znacznej długości poprowadzony jest hipotetycznie na podstawie informacji historycznych $\mathrm{w}$ nawiązaniu do zachowanej infrastruktury. Wchodzące w ich skład pełne odcinki rowów strzeleckich mierzyły do $3 \mathrm{~km}$ długości (na Makowskiej Górze) (Sadowski 2009). Natomiast wykorzystując dane LiDAR na obszarze województwa świętokrzyskiego zdołano odtworzyć dwie zachowane w terenie linie okopów, spośród których dłuższa mierzy nieco ponad $7 \mathrm{~km}$ długości (Szady, Zapłata 2014). Do dobrego stanu ich zachowania przyczyniło się kilka czynników. Jednym z najważniejszych jest fakt, iż linia umocnień nie została zniszczona w trakcie działań wojennych, ponieważ główna linia frontu ominęła ten odcinek umocnień. Ponadto większość okopów wykonana została na obszarach leśnych, przez co po zakończeniu II wojny światowej nie były one zasypywane przez miejscową ludność w celu odzyskania gruntów uprawnych. Z kolei brak wykorzystania przy ich budowie trwałych materiałów budowlanych (metali, drewna) uchronił je przed niszczeniem w celu wtórnego wykorzystania tych materiałów w budownictwie. Natomiast w związku z wykonaniem ich w twardym podłożu (często z wykorzystaniem bloków piaskowca magurskiego) umocnienia 
te nie ulegały łatwo niszczącej działalności ruchów masowych. Zachowały się w znacznie lepszym stanie w przeciwieństwie do linii umocnień utworzonych w obrębie luźnych utworów (piasków) (Śledziński 2009). Najsłabiej zachowały się nieliczne fragmenty linii okopów przebiegających przez pola uprawne, które obecnie zamienione zostały w nieużytki.

Obie zastosowane metody okazały się mieć swoje mocne i słabe strony (Franczak, Jucha 2015), które wzajemnie się uzupełniają.

Przeprowadzenie kartowania terenowego zapobiega popełnieniu błędu w interpretacji obrazu uzyskanego z danych LiDAR. Pozwoliło ono na poprawną identyfikację linii okopów i odróżnieniu ich od innych liniowych obiektów, jak drogi. W innych obszarach czynność ta umożliwia także odróżnienie okopów od innych obiektów liniowych, jak torowiska i umocnienia kolei wąskotorowej (Sztampke 2014). Na badanym obszarze należało jednak odróżnić te formy od dróg leśnych i polnych oraz ich pozostałości. Drogi leśne oraz szlaki zrywkowe w obrazie z danych LiDAR są znacznie szersze, często głębiej wcięte i charakteryzują się innym przebiegiem w obrębie stoku (Stereńczak 2010; Kucharzyk 2015). Poprowadzone linie okopów łagodnie trawersują wzdłuż grzbietu na stoku (ryc. 6). Okopy wojskowe od dróg śródleśnych $\mathrm{w}$ obrazie z LiDAR odróżnia również występowanie wypustek odchodzących od głównej linii. Tego typu cechy zauważone podczas badań linii okopów w województwie świętokrzyskim (Szady, Zapłata 2014) zaobserwowano także na obszarze badań. Związane są one z występowaniem obiektów punktowych, które zaznaczają się w danych z LiDAR, lecz identyfikacja ich typu nastąpić musi w wyniku przeprowadzonych badań terenowych. Dotyczy to zwłaszcza małych obiektów, głównie stanowisk strzelniczych. Znacznie większe schrony bierne wyraźnie zaznaczają się w obrazie z wygenerowanego numerycznego modelu terenu LiDAR i na jego podstawie można je zidentyfikować.

Rozmiary obiektów utworzone w ramach umocnień OKH Stellung b1 cechują się standardowymi rozmiarami. Zinwentaryzowane na obszarze badań obiekty nawiązują do rozmiarów form zinwentaryzowanych w Beskidzie Makowskim (Sadowski 2009), w odcinku południowym linii OKH Stellung b1 (w województwie małopolskim i śląskim) (Śledziński 2009) i linii umocnień w województwie świętokrzyskim (Szady, Zapłata 2014). Jedynie na niewielkich odcinkach w związku ze specyfiką terenu (duże nachylenie stoków, położenie w obrębie osuwisk), elementy te ulegały modyfikacji poprzez m.in. wykonanie węższych rowów strzeleckich.

\section{Podsumowanie}

Na podstawie uzyskanych wyników badań oraz zalet wynikających ze stosowania danych z LiDAR w badaniach kulturowych (archeologicznych) nad infrastrukturą obronną z okresu II wojny światowej zaleca się prowadzenie prac badawczych $\mathrm{i}$ inwentaryzacyjnych $\mathrm{w}$ innych regionach. Metoda ta pozwala na zidentyfikowa- 
nie linii okopów rozmieszczonych na rozległym, często trudno dostępnym obszarze, przez co wskazana jest do stosowania podczas prowadzonych badań na obszarze Karpat. Uzyskane wyniki stanowią także podstawę do dalszych prac badawczych nad historią tworzenia infrastruktury obronnej w regionie.

$\mathrm{W}$ celu szczegółowego rozpoznania obiektów, badania $\mathrm{z}$ użyciem danych z LiDAR należy rozszerzyć o badania terenowe mające za zadanie identyfikację małych powierzchniowo oraz płytkich obiektów punktowych. Ponadto należy stwierdzić, że pozostałości dawnych linii obronnych przebiegających na zalesionych obszarach górskich są stosunkowo trwałym elementem, rozpoznawalnym w krajobrazie i rzeźbie terenu nawet po 70 latach od zakończenia II wojny światowej. $\mathrm{Z}$ tego powodu obiekty te należy uznać za ważny element krajobrazu i dążyć do ich zachowania dla przyszłych pokoleń jako elementu świadczącego o dawnej historii regionu.

\section{Podziękowanie}

Autorzy pragną podziękować Recenzentom za bardzo cenne uwagi i sugestie.

\section{LITERATURA}

Ackermann F., 1999, Airborne laser scanning: present status and future expectations, „ISPRS Journal of Photogrammetry and Remote Sensing”, 54(2-3), s. 64-67.

Balon J., Jodłowski M., 2005, Regionalizacja fizycznogeograficzna pogranicza polsko-słowackiego, [w:] Strzyż M. (red.), Perspektywy rozwoju regionu w świetle badań krajobrazowych, „Problemy Ekologii Krajobrazu”, 12, s. 69-76.

Banaszek Ł., 2014, Lotniczy skaning laserowy w polskiej archeologii. Czy w petni wykorzystywany jest potencjat prospekcyjny metody?, „Folia Praehistorica Posnaniensia”, 19 , s. 207-250.

Banaszek Ł., Rączkowski W., 2010, Archeologia w lesie. O identyfikacji stanowisk archeologicznych w gminie Polanów (i nie tylko), [w:] Rączkowski W., Sikora J. (red.), Miasto i gmina Polanów. Historia i kultura Ziemi Stawieńskiej, t. 10, s. 117-131.

Bednarz S., Sadowski P., 2009, Działania wojenne w rejonie Babiej Góry we wrześniu 1939 roku, „Rocznik Babiogórski”, 11, s. 31-88.

Challis K., 2006, Airborne laser altimetry in alleviated landscapes, „Archaeological Prospection", 13(2), s. 103-127.

Devereux B., Amable G., Crow P., Cliff A., 2005, The potential of airborne lidar for detection of archaeological features under woodland canopies, „Antiquity”, 79, s. 648-660.

Figiel S., Janicka-Krzywda U., Krzywda P., Wiśniewski W.W., 2006, Beskid Żywiecki, Oficyna Wydawnicza „Rewasz”, s. 221-223.

Franczak P., Jucha W., 2015, Porównanie przydatności danych z kartowania terenowego $i$ interpretacji modelu terenu wygenerowanego $z$ danych LiDAR do rozpoznania infrastruktury obronnej z II wojny światowej w Paśmie Jatowieckim, Prace Studenckiego Koła Naukowego Geografów Uniwersytetu Pedagogicznego w Krakowie, 4, Wydawnictwo UP, Kraków, s. 36-48.

Fuglewicz S., 1995, Problematyka terminologii i systematyki fortyfikacji najnowszej, „Fortyfikacja”, 3, Warszawa-Kraków, s. 152-161. 
Holden N., Horne P., Bewley R.H., 2002, High-resolution digital airborne mapping and archaeology, [w:] Bewley R.H, Rączkowski W. (red.), Aerial Archaeology: Developing Future Practice, Amsterdam, s. 173-180.

Hug C., Ullrich A., Grimm A., 2004, Litemapper-5600 - A Waveform-Digitizing LiDAR Terrain and Vegetation Mapping System, [w:] Thies M., Koch B., Spiecker H., Weinacker H. (red.), Laser-Scanners for Forest and Landscape Assessment, International Archives of Photogrammetry and Remote Sensing, s. 24-29.

Kantyka J., 1985, Na beskidzkich szlakach. Z dziejów walk z okupantem hitlerowskim, Wydawnictwo Śląs, Katowice, s. 45-49.

Kastelik A., Jucha W., Rosiek J., 2013, Fortyfikacje stałe w Węierskiej Górce w przededniu II wojny światowej - przegląd za pomoca współczesnych narzędzi geograficznych, Prace Studenckiego Koła Naukowego Geografów Uniwersytetu Pedagogicznego w Krakowie, 2, Wydawnictwo UP, Kraków, s. 63-75.

Kondracki J., 2009, Geografia regionalna Polski, Wydawnictwo Naukowe PWN, Warszawa, s. 327-328.

Kucharzyk S., 2015, Dawne oraz współczesne drogi leśne i szlaki zrywkowe w waloryzacji naturalności ekosystemów leśnych w Bieszczadach, „Roczniki Bieszczadzkie”, 23, s. 95-109.

Maclean G., Krabill W., 1986, Gross-merchantable timber volume estimation using an airborne lidar system, „Canadian Journal of Remote Sensing”, 12, s. 7-18.

Medyńska-Gulij B., 2011, Kartografia i geowizualizacja, Wydawnictwo Naukowe PWN, Warszawa, s. 162-165.

Mendrygał Z. (red.), 1976, Encyklopedia Techniki Wojskowej, Wydawnictwo Ministerstwa Obrony Narodowej, Warszawa, s. 444-445, 624.

Mydlarz J., 2009, Skawica od 1900 do 1939 roku, [w:] Harasimczyk J.H. (red.), Królewska wieś: monografia Skawicy, Wydawnictwo Faktoria Wyrazu,Skawica-Kraków,s.69-87.

Nelson R., Krabill W., Maclean G., 1984, Determining forest canopy characteristics using airborne laser data, ,Remote Sensing of Environment”, 15, s. 201-212.

Nowakowski J., 2010, Airborne Laser Scanning (ALS) w polskiej archeologii. Próby, doświadczenia, wyniki, Referat wygłoszony na konferencji: XIX Konferencja Sprawozdawcza. Badania archeologiczne na Nizinie Wielkopolsko-Kujawskiej w latach 2008-2009, Poznań.

Od zapomnienia do zagospodarowania, Biuletyn Miłośników Fortyfikacji „INFORT numer specjalny 2 - Fortyfikacje II wojny światowej”, s. 4-19.

Rawski T., 1966, Niemieckie umocnienia na ziemiach polskich $w$ latach 1919-1945, [w:] „Studia i Materiały do Historii Wojskowości”, 12, s. 281-301.

Rosiek J., 2014, Zęby Smoka w Leśnej, „Nowiny Lipowskie”, s. 17.

Sadowski P., 2009, Niemieckie fortyfikacje z 1944 roku w Beskidzie Myślenickim - budowa, wykorzystanie bojowe, stan obecny, [w:] Od zapomnienia do zagospodarowania, Biuletyn Miłośników Fortyfikacji „INFORT - numer specjalny 2 - Fortyfikacje II wojny światowej", s. 20-35.

Sadowski P., 2011, Druga wojna światowa pod Babia Górą. Księga Strat, Wydawnictwo SGB, Kraków-Zawoja, ss. 488.

Sadowski P., 2013, Jordanów w czasie II wojny światowej, [w:] Bednarz S., Sadowski P. (red.), Jordanów: monografia miasta, Wydawnictwo TMZJ, Bielsko-Biała, s. 235-282.

Shell C., Roughley C., 2004, Exploring the Loughcrew landscape: a new airborne approach, „Archaeology Ireland”, 18/2 (68), s. 22-25. 
Sittler B., 2004, Revealing historical landscapes by using airborne laser scanning, a 3-d model of ridge and furrow in forests near Rastatt, Germany, [w:] Thies M., Koch B., Spiecker H., Weinacker H. (red.), Laser-Scanners for Forest and Landscape Assessment, International Archives of Photogrammetry and Remote Sensing, s. 258-261.

Sławik Ł., Zapłata R., 2010, Lidar zmienia archeologie,, „Geodeta”, Magazyn Geoinformacyjny, 10(185), s. 66-68.

Sołoduchin W.I., Kulasow A.G., Utenkow B.I., Żukow A.J., Mażugin I.N., Emalanow W.P., Kopolow I.A., 1977, Sjomka profila krony dieriewa s pomoszczju laziernego dalnomiera, „Lesnoje Choziajstwo”, 2, s. 71-73.

Steblik W., 1989, Armia Kraków 1939, Wydawnictwo Ministerstwa Obrony Narodowej, Warszawa, ss. 692.

Sterańczak K., 2010, Technologia lotniczego skaningu laserowego jako źródło danych w półautomatycznej inwentaryzacji lasu, „Sylwan”, 154(2), s. 88-99.

Suchanek P., 2004, Fortyfikacje Jeleśni, Przyborów-Krzyżowa-Żywiec, s. 4-7.

Szady B., Zapłata R., 2014, Analiza danych, weryfikacja terenowa i próba interpretacji, [w:] Sztampke M. (red.), Laserowi odkrywcy. Nieinwazyjne badanie i dokumentowanie obiektów archeologicznych i historycznych województwa świętokrzyskiego, Wydawnictwo Centrum GeoHistorii, Stare Babice, s. 111-162.

Sztampke M. (red.), 2014, Laserowi odkrywcy. Nieinwazyjne badanie i dokumentowanie obiektów archeologicznych i historycznych województwa świętokrzyskiego, Wydawnictwo Centrum GeoHistorii, Stare Babice.

Śledziński M., 2009, Pozycja b-1. Odcinek poludniowy na tle innych niemieckich fortyfikacji z roku 1944, [w:] Od zapomnienia do zagospodarowania, Biuletyn Miłośników Fortyfikacji ,INFORT - numer specjalny 2-Fortyfikacje II wojny światowej”, s.20-35.

Wehr A., Lohr U., 1999, Airborne laser scanning - an introduction and overview, „ISPRS Journal of Photogrammetry and Remote Sensing", 54(2-3), s. 68-82.

Zaloga S., 1996, Bagration 1944: The Destruction of Army Group Centre, Osprey Publishing, Wellingborough, ss. 96.

Zapłata R., 2013, Nieinwazyjne metody w badaniu i dokumentacji dziedzictwa kulturowego - aspekty skanowania laserowego w badaniach archeologicznych $i$ architektonicznych, Warszawa.

\section{Źródla internetowe}

Furmanek M., Mackiewicz M., Myślecki B., Ufortyfikowane osiedla z epoki brązu i epoki żelaza na Ślasku w świetle lotniczego skanowania laserowego, http://www.academia. edu/10669508/Ufortyfikowane_osiedla_z_epoki_...(dostęp: 1.08.2015).

Quantum GIS Project - http://qgis.org/ (dostęp: 1.08.2015).

FUSION/LDV: Software for LiDAR data and visualization, http://forsys.cfr.washington. edu/fusion/ (dostęp: 1.08.2015).

Legut-Pintal M., 2012, LiDAR w badaniach nad średniowiecznymi fortyfikacjami i siedzibami obronnymi. Przykład założeń obronnych Księstwa Biskupów Wrocławskich, http://www.academia.edu/3102476/LiDAR_w_badaniach_nad_sredniowiecznymi_fo rtyfikacjami_i_siedzibami_obronnymi._Przyklad_zalozen_obronnych_ksiestwa_bisk upow_wroclawskich (dostęp: 01.10.2015). 


\title{
RECONSTRUCTION OF TRENCH LINE FROM SECOND WORLD WAR (OKH Stellung b1) IN JALOWIEC RANGE AND MĘDRALOWA MOUNTAIN GROUP BY INTERPRETATION OF LiDAR DATA MODEL AND FIELD RESEARCH
}

\begin{abstract}
LiDAR (Light Detection And Ranging) data are very useful in geographical, historical and archeological studies. It is because of large ALS point cloud precision, which makes possibility of studying small forms in relief, such as unmetalled roads, historical agricultural systems, archaeological sites or old field fortifications, like trench lines.

The aim of this article is test on the usability of LiDAR data in research of trench lines built during Second World War in Poland, in Beskidy Mountains. The study area chosen to this text was located in Jałowiec Range and Mędralowa Mountain Group in south-west of Małopolskie voivodeship, south of Poland (Fig. 1). Jałowiec Range and Mędralowa Mountain Group is a continuation to the north of the Massif Babia Góra (Beskid Żywiecki, Carpathians). The fortifications were been built in this area before and during the Second World War. The first objects were built by Polish Army in 1939 and second time there was built two large fortification lines 1944, by polish people forced to do it by german soldiers. The most objects in studied area were made on the slopes of Malikowski Groń. Objects founded in 1944 were preserved in good condition up to the present day (Tab. 1). The few objects have been transformed by the geomorphological processes and by overgrown trees and shrubs on them. These objects have survived to this day, because they were not damaged during hostilities. The research was performed on a piece of trench line on Malikowski Groń (760 ma.s.l.) about 12,2 km long (Fig. 3, Fig. 6), Lachów Groń (708 m a.s.1.) about 1,6 km long (Fig. 3) and Mędralowa Mountain Group (1169 m a.s.l) about 2,3 km long (Fig. 4). During the field test the plan of trench lines (Fig. 3C, 5B) was performed by using GPS mapping and by measurement of the size and depth of the trenches. Second plan (Fig. 3B, 5A) is the result of LiDAR data analyses and vectorization. After then the obtained results were compared in research analysis. The trench lines and objects are quite good visible in LiDAR data, but it is impossible to do the classification of point objects made in field observation (Tab. 1, 2, 3). However, as a general comment, it is the possibility to signing the object classes in neighbor areas by way of analogy to field testing research.
\end{abstract}

Key words: LiDAR, fortifications, trenches, The Second World War, LiDAR, Carpathians.

Mgr Paweł Franczak Instytut Geografii i Gospodarki Przestrzennej Uniwersytet Jagielloński

Mgr inż. Witold Jucha Instytut Geografii Uniwersytet Pedagogiczny im. Komisji Edukacji Narodowej w Krakowie 